\title{
The Influence Of Pricing Rate And Word Of Mouth (Wom) Mediated By Trust On Credit Car Purchasing Decisions
}

\author{
Soegeng Wahyoedi ${ }^{1}$, Andry ${ }^{2 *}$ \\ ${ }^{1,2}$ Faculty of Economic and Business, Krida Wacana Christian University \\ ${ }^{*}$ Corresponding Author: \\ Email: andrytan7822@gmail.com
}

\begin{abstract}
.
Intense competition between finance companies makes each must apply the best strategy to become a winner. This study aims to analyze the direct effect of pricing rate and word of mouth (wom) on purchasing decisions and indirectly mediated by trust, as well as the direct influence of trust on purchasing decisions. The population of this study is consumers who have purchased a car on credit at Maybank Finance in the West Java area, which consists of 4 city branches, namely: Bandung, Bogor, Cirebon and Karawang, both those that have been paid off and those that are still running. Samples were taken as many as 100 respondents using non-probability sampling technique with quota sampling method. Data analysis using Partial Least Square (PLS) using SmartPLS software. The results show that all hypotheses are proven to have an influence on pricing rate, word of mouth (wom) and trust on purchasing decisions, and it is also proven that trust is able to mediate the relationship between these variables.
\end{abstract}

Keywords: Pricing Rate, Word of Mouth, Trust, Purchasing Decisions.

\section{INTRODUCTION}

Transportation in modern life has become an important thing, especially in everyday life, to move and move quickly from one place to another. In general, transport is divided into three types, namely: sea transportation, air transportation, and land transportation. One means of land transportation is a car. The increasing need for this car has become an excellent opportunity for auto business players to continue to increase their sales. In Indonesia, several types and brands of vehicles are in circulation, including Toyota, Honda, Daihatsu, Suzuki, Mitsubishi, Nissan, Wuling, and many others. However, sometimes the need for this car is constrained by the high price of the vehicle and financial factors that are not sufficient to buy a car. Not everyone has the money to buy a car in cash, but they can buy a car on credit. The solution for buying a car on credit is to use a finance company as a service company. Finance companies can help purchase vehicles on credit by paying installments following the agreed installments every month, calculated based on the down payment, interest, and period.There are quite a several car financing companies in Indonesia, one of which is PT. Maybank Indonesia Finance or Maybank Finance, established in Indonesia in 1991, was previously named PT. BII Finance Center or BII Finance, but in 2015 changed its name to PT. Maybank Indonesia Finance or Maybank Finance. Now Maybank Finance has 34 branches and nine representative offices spread throughout Indonesia.

The decision to purchase a car on credit is influenced by financial factors and the increasing need for car vehicles. Still, it is also influenced by other factors, one of which is the pricing rate factor. The high level of competition between finance companies in Indonesia allows consumers to choose a finance company that suits their needs, especially finance companies that offer low pricing rates. Research conducted by Winoto (2020) that price is one factor that influences consumer purchasing decisions. By providing attractive and competitive prices and special price discounts, the demand for a product or service offered will increase, and vice versa. If the price of the product or service provided is higher, the order will also be lower. This is supported by research from Maurencia et al. (2021), Sukawati (2018), Putra and Purbawati (2019), and Masturi and Hardini. (2017) To maintain existence and gain market share so that consumers purchasing cars on credit can choose to use Maybank Finance, Maybank Finance applies a pricing strategy that attracts the public, namely low installments and interest rates.Along with the development of the economy in Indonesia today, apart from the pricing rate, 
there are other factors, namely non-price factors, that also influence consumer purchasing decisions. According to Arif and Putri (2020), word of mouth (wom) affects decision-making or consumer buying behavior. The experiences that consumers get in using a product or service, they will express honestly to others, especially to those closest to them, whether it's a good or bad experience if they get a good experience and maximum results, they will give good comments, praise and also the recommendation of the product or service to others, and vice versa.

This is also supported by Putra and Purbawati (2019) research, Fhonna and Utami (2018), and Pratiwi (2017).Another non-price factor that influences consumer purchasing decisions is trust. In Arif and Putri's research (2020), trust is essential for consumers to make purchasing decisions. Trust also helps a company's sustainability because if a company's products or services are trusted, then the product or service will develop in the market. Then in the research of Rico et al. (2018) explains that trust is a condition where the party conducting the exchange process believes in the reliability and integrity of the other party, while Fansisca and Saparso (2014) state that trust is a guideline for consumers to make decisions in purchasing, where the higher the level of trust, the higher the purchase decision. Created will also be higher. The research of Japarianto and Adelia (2020) and Murwatiningsih and Apriliani (2018) stated that trust has a mediating role in influencing price levels on purchasing decisions. In addition, research by Octavini (2020) and Haekal et al., (2016), and Fhonna and Utami (2018) concluded that trust also plays a role in mediating the influence of word of mouth (wom) on purchasing decisions. Trust is when consumers trust a company and then make repeat purchases and share personal information with the company.

\section{Pricing Rate}

Kotler and Armstrong (2020:278) state that the price level is a rate, which is a number that shows the value, price, speed of development, and production based on specific units of measurement, premium costs, insurance, or expenses. The high and low levels of fees are always the primary concern of consumers when looking for a product, so the price offered is a special consideration before they decide to buy goods or use a service. Therefore, the price level strategy is very influential in increasing sales of a particular product or service. According to Kotler and Armstrong (2020) in Maurencia et al. (2021), there are four price level indicators: price affordability, price conformity to product quality, price suitability with benefits, and price according to ability or price competitiveness.

\section{Word of Mouth (WoM)}

Priansa (2017: 339) states that "word of mouth (wom) is a message or information about the company, as well as the products or services of the company, in the form of comments about the company, product performance, friendliness, honesty, speed of service, experience using products and other things that are experienced and felt by someone which is then told to others." There are five elements (Five Ts) in the spread of word of mouth, (wom) according to Sernovitz (2014) in Pratiwi (2017) as follows: Speakers, Topics, Tools, Participation, and Supervision.

\section{Trust}

Rico et al. (2018) explain that trust is a condition where the party conducting the exchange process believes in the reliability and integrity of the other party. Wahyoedi and Winoto (2018) describe that trust is the belief that consumers will find what they want in providers of goods and services. According to Daryanto (2013), trust is a person's belief that his exchange partner will be able to fulfill what he wants and hopes that one's promises, words, or statements can be trusted. According to Connolly and Bannister (2007) in Fhonna and Utami (2018), there are five indicators in the trust variable, namely: good experience, helpful information, safe and reliability, ease to trust, and get satisfaction.

\section{Purchasing Decisions}

Purchasing decision refers to a type of decision making that studies the reasons for buying a particular brand by customers (Amitay et al., 2020). Peter and Olson (2013:163) argue that "purchase decisions are an 
integration process by combining knowledge to evaluate two or more alternative behaviors and choose one of them." According to Suryani (2013), purchasing decisions are decisions taken by someone because they are influenced by stimuli or stimuli from outside or from within a person. According to Malau (2017) in Winoto (2020), there are five indicators in purchasing decision variables: needing recognition, seeking information, evaluating alternatives, purchasing decisions, and post-purchase behavior.

\section{Conceptual Framework and Hypothesis}

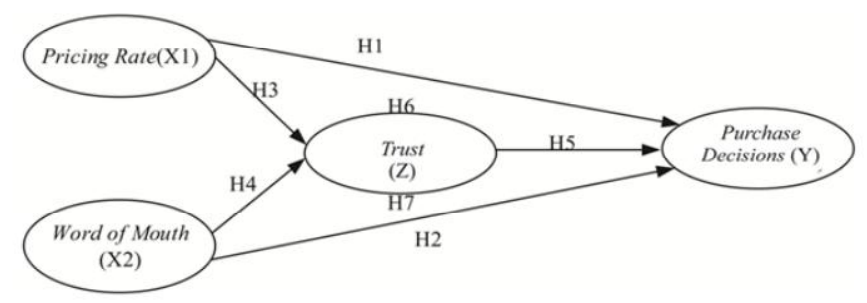

Fig 1. Research Framework

H1: Pricing rate affects purchasing decisions.

H2: Word of mouth (WoM) affects purchasing decisions.

H3: Pricing rate affects trust.

H4: Word of mouth (WoM) affects trust.

H5: Trust affects purchasing decisions.

H6: Trust mediates the pricing rate on purchasing decisions.

H7: Trust mediates word of mouth (wom) on purchasing decisions.

\section{METHODS}

The population in this study are all consumers who have purchased a car on credit at the Maybank Finance area of West Java which consists of 4 city branches, namely: Bandung, Bogor, Cirebon, and Karawang, both those that have been paid off and those that are still running, where the total population is for consumers who are still running are known, but the people of consumers who have paid off is unknown, so the overall population in this study is unknown. The sampling method in this study uses a non-probability sampling technique with a quota sampling method. Collect data by distributing questionnaires directly to consumers who come to the Maybank Finance branch offices in the West Java area, namely Bandung, Bogor, Cirebon, and Karawang branches, where each branch has 25 research samples total of 100 respondents. The data analysis technique uses Partial Least Square (PLS) with SmartPLS software. The analysis used is the analysis of the outer model, inner model, and hypothesis analysis.

\section{RESULT AND DISCUSSION Validity and Reliability Test Result}

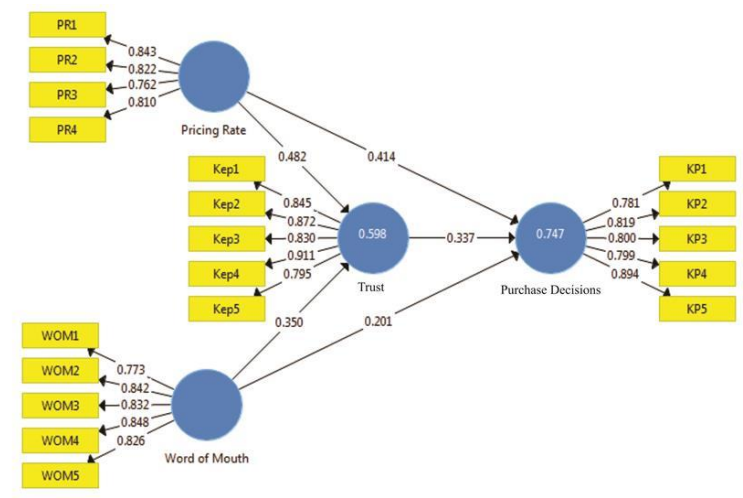

Fig 2. Construct Model 
Table 1. Loading Factors

\begin{tabular}{|l|c|c|}
\hline \multicolumn{1}{|c|}{ Variable } & Items & Loading Factor \\
\hline \multirow{4}{*}{ Pricing Rate (X1) } & PR1 & 0,843 \\
\cline { 2 - 3 } & PR2 & 0,822 \\
\cline { 2 - 3 } & PR3 & 0,762 \\
\cline { 2 - 3 } & PR4 & 0,810 \\
\hline \multirow{5}{*}{ Word of Mouth (X2) } & WOM1 & 0,733 \\
\cline { 2 - 3 } & WOM2 & 0,842 \\
\cline { 2 - 3 } & WOM3 & 0,832 \\
\cline { 2 - 3 } & WOM4 & 0,848 \\
\hline \multirow{3}{*}{ Trust (Z) } & WOM5 & 0,826 \\
\cline { 2 - 3 } & Kep1 & 0,845 \\
\cline { 2 - 3 } & Kep2 & 0,872 \\
\cline { 2 - 3 } & Kep3 & 0,830 \\
\cline { 2 - 3 } & Kep4 & 0,911 \\
\hline \multirow{3}{*}{ Purchasing Decisions (Y) } & Kep5 & 0,795 \\
\cline { 2 - 3 } & KP1 & 0,781 \\
\cline { 2 - 3 } & KP2 & 0,819 \\
\cline { 2 - 3 } & KP3 & 0,800 \\
\cline { 2 - 3 } & KP4 & 0,799 \\
\hline
\end{tabular}

Table 2. Cross Loadings

\begin{tabular}{|c|c|c|c|c|}
\hline Items & Pricing Rate & Word of Mouth & Trust & $\begin{array}{c}\text { Purchasing } \\
\text { Decisions }\end{array}$ \\
\hline PR1 & 0,843 & 0,562 & 0,548 & 0,728 \\
\hline PR2 & 0,822 & 0,623 & 0,650 & 0,676 \\
\hline PR3 & 0,762 & 0,469 & 0,516 & 0,520 \\
\hline PR4 & 0,810 & 0,671 & 0,653 & 0,672 \\
\hline WOM1 & 0,589 & 0,733 & 0,585 & 0,622 \\
\hline WOM2 & 0,551 & 0,842 & 0,607 & 0,616 \\
\hline WOM3 & 0,606 & 0,832 & 0,534 & 0,599 \\
\hline WOM4 & 0,606 & 0,848 & 0,545 & 0,566 \\
\hline WOM5 & 0,632 & 0,826 & 0,600 & 0,628 \\
\hline Kep1 & 0,576 & 0,563 & 0,845 & 0,576 \\
\hline Kep 2 & 0,607 & 0,611 & 0,872 & 0,684 \\
\hline Kep 3 & 0,667 & 0,562 & 0,830 & 0,664 \\
\hline Kep 4 & 0,641 & 0,660 & 0,911 & 0,714 \\
\hline Kep 5 & 0,631 & 0,569 & 0,795 & 0,680 \\
\hline KP1 & 0,624 & 0,637 & 0,662 & 0,781 \\
\hline KP2 & 0,626 & 0,631 & 0,623 & 0,819 \\
\hline KP3 & 0,672 & 0,582 & 0,630 & 0,800 \\
\hline KP4 & 0,618 & 0,485 & 0,562 & 0,799 \\
\hline KP5 & 0,758 & 0,668 & 0,715 & 0,894 \\
\hline
\end{tabular}

Table 3. Discriminant Validity

\begin{tabular}{|l|c|c|c|c|}
\hline & Trust & $\begin{array}{c}\text { Purchasing } \\
\text { Decisions }\end{array}$ & Pricing Rate & Word of Mouth \\
\hline Trust & 0,851 & & & \\
\hline Purchasing Decisions & 0,782 & 0,819 & & \\
\hline Pricing Rate & 0,735 & 0,808 & 0,810 & \\
\hline Word of Mouth (WoM) & 0,698 & 0,737 & 0,724 & 0,825 \\
\hline
\end{tabular}

Table 1 shows the results of the loading factor having a value above 0.7 . So, it can be said that the research data is said to be valid. From table 2 , it can be seen that the cross-loading value greater than 0.7 and the research data 
can be said to be valid. From table 3, from the discriminant validity it can be seen that the value of the crossloading is $>0.7$, so by fulfilling these conditions, it can be stated that this study is valid.

Table 4. Average Variance Extracted

\begin{tabular}{|l|l|}
\hline \multicolumn{1}{|c|}{ Variable } & AVE \\
\hline Pricing Rate & 0,656 \\
\hline Word of Mouth (WoM) & 0,680 \\
\hline Trust & 0,725 \\
\hline Purchasing Decisions & 0,671 \\
\hline
\end{tabular}

From table 4, the Average Variance Extracted of all variables is above 0.5, meaning that the research conducted has met the requirements of the convergent validity test.

Table 5. Composite Reliability

\begin{tabular}{|l|c|}
\hline & Composite Reliability \\
\hline Pricing Rate & 0,884 \\
\hline Word of Mouth (WoM) & 0,914 \\
\hline Trust & 0,929 \\
\hline Purchasing Decisions & 0,911 \\
\hline
\end{tabular}

From table 5, the composite reliability value of all research variables is above 0.7 , so it can be concluded that all variables in this study are said to be reliable, meaning they are considered to have good reliability.

Table 6. R-Square Coefficient

\begin{tabular}{|l|c|}
\hline \multicolumn{1}{|c|}{ Variable } & R-square \\
\hline Trust $(\mathrm{Z})$ & 0,598 \\
\hline Purchasing Decisions (Y) & 0,747 \\
\hline
\end{tabular}

The table above shows the R-square value of Trust $(\mathrm{Z}) 59.8 \%$. This means that the pricing rate and word of mouth (WOM) variables together affect the trust variable by $59.8 \%$, and the remaining $40.2 \%$ is influenced by other variables not examined. While the R-square value of the Purchase Decision (Y) is $74.7 \%$, this means that the pricing rate, word of mouth, and trust variables affect the purchasing decision variables by $74.7 \%$, and the remaining $25.3 \%$ is influenced by other variables. which were not researched.

\section{Hypothesis Analysis - Direct Effect}

Test the direct influence hypothesis using path analysis (path analysis) using SmartPLS. Bootstrapping method is used to determine the value of T-statistics as was done in the SEM Partial Least Square model. (Ghozali and Latan, 2015).

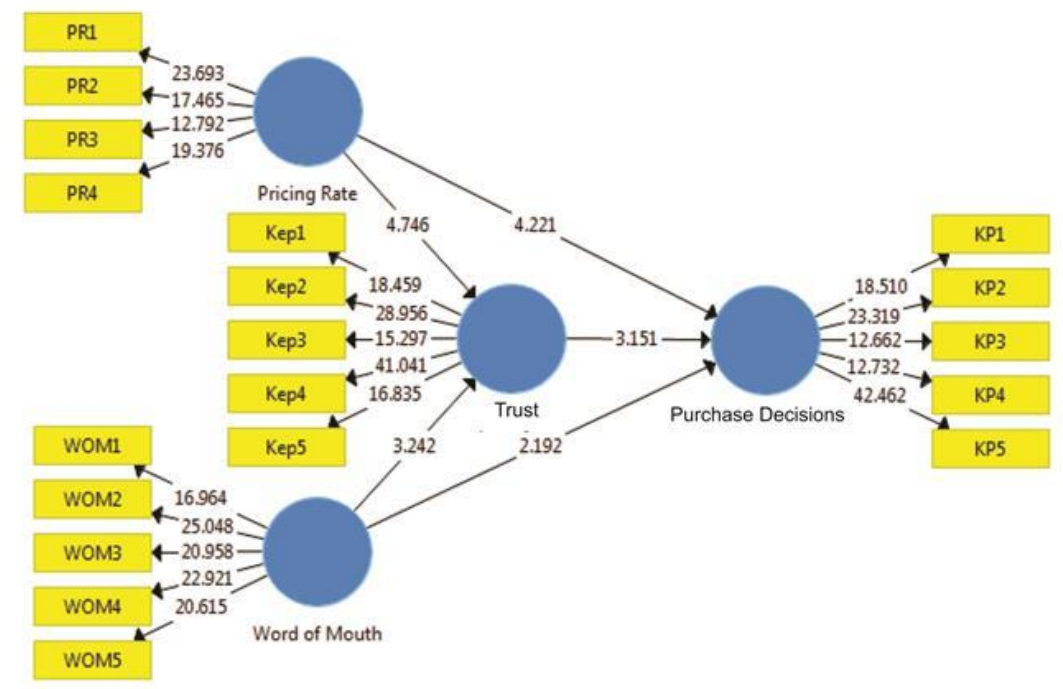

Fig 3. Bootstrapping Model 
Table 7. Path Coefficient

\begin{tabular}{|l|c|c|c|c|c|}
\hline & $\begin{array}{c}\text { Original } \\
\text { Sample } \\
(\mathrm{O})\end{array}$ & $\begin{array}{c}\text { Sample } \\
\text { Mean } \\
(\mathrm{M})\end{array}$ & $\begin{array}{c}\text { Standard } \\
\text { Deviation } \\
\text { (STDEV) }\end{array}$ & $\begin{array}{c}\text { T - } \\
\text { Statistic }\end{array}$ & $\begin{array}{c}\text { P - } \\
\text { Values }\end{array}$ \\
\hline Pricing Rate $\rightarrow$ Purchasing Decisions & 0.414 & 0.405 & 0.098 & 4.221 & 0.000 \\
\hline Word of Mouth $\rightarrow$ Purchasing Decisions & 0.201 & 0.206 & 0.092 & 2.192 & 0.029 \\
\hline Pricing Rate $\rightarrow$ Trust & 0.482 & 0.489 & 0.101 & 4.746 & 0.000 \\
\hline Word of Mouth $\rightarrow$ Trust & 0.350 & 0.341 & 0.108 & 3.242 & 0.001 \\
\hline Trust $\rightarrow$ Purchasing Decisions & 0.337 & 0.344 & 0.107 & 3.151 & 0.002 \\
\hline
\end{tabular}

This study tested five existing direct influence hypotheses, namely as follows:

\section{a. $\quad$ First Hypothesis Test (H1)}

The first hypothesis test tests the effect of the pricing rate (price level) on the decision to purchase a car on credit. Based on table 4.19, the results of hypothesis testing obtained are: T-statistic 4.221>1.96 and P-value $0.0000<0.05$. So the first hypothesis is accepted. The pricing rate influences purchasing decisions, meaning that if the pricing rate given by the company is low, it will cause an increase in the decision to purchase cars on credit.

\section{b. Second Hypothesis Test (H2)}

The second hypothesis test tested the effect of word of mouth (wom) on the decision to buy a car on credit. Based on table 4.19, the results of hypothesis testing obtained are: T-statistic $2.192>1.96$ and P-value $0.029<0.05$. So the second hypothesis is accepted, word of mouth influences purchasing decisions, meaning that if word of mouth is positive, it will cause an increase in car buying decisions on credit.

\section{c. Third Hypothesis Test (H3)}

The third hypothesis test tests the effect of the pricing rate (price level) on trust. Based on table 4.19, the results of hypothesis testing obtained are: T-statistic $4.746>1.96$ and P-value $0.000<0.05$. So the third hypothesis is accepted, the pricing rate influences trust, meaning that an appropriate and competitive pricing rate (price level) will affect consumer confidence.

\section{d. Fourth Hypothesis Test (H4)}

The fourth hypothesis test is to test the effect of word of mouth (wom) on trust. Based on table 4.19, the results of hypothesis testing obtained are: T-statistic 3,242>1.96 and P-value $0.001<0.05$. So the fourth hypothesis is accepted, word of mouth influences trust, meaning that if positive word of mouth will increase consumer confidence.

\section{e. Fifth Hypothesis Test (H5)}

The fifth hypothesis test tests the influence of trust on the decision to buy a car on credit. Based on table 4.19, the results of hypothesis testing obtained are: T-statistic $3.151>1.96$ and P-value $0.002<0.05$. So the fifth hypothesis is accepted, trust influences purchasing decisions, meaning that if trust increases, it will affect carbuying decisions on credit.

Hypothesis Analysis - Indirect Effect

Table 8. Mediating Effect

\begin{tabular}{|l|c|c|c|c|c|}
\hline & $\begin{array}{c}\text { Original } \\
\text { Sample } \\
(\mathrm{O})\end{array}$ & $\begin{array}{c}\text { Sample } \\
\text { Mean (M) }\end{array}$ & $\begin{array}{c}\text { Standard } \\
\text { Deviation } \\
(\text { STDEV) }\end{array}$ & T -Statistic & P-Values \\
\hline $\begin{array}{l}\text { Pricing Rate } \rightarrow \text { Trust } \rightarrow \text { Purchasing } \\
\text { Decisions }\end{array}$ & 0.163 & 0.168 & 0.062 & 2.614 & 0.009 \\
\hline $\begin{array}{l}\text { Word of Mouth } \rightarrow \text { Trust } \rightarrow \text { Purchasing } \\
\text { Decisions }\end{array}$ & 0.118 & 0.118 & 0.054 & 2.204 & 0.028 \\
\hline
\end{tabular}


From the results of the significance test for the mediating effect above, the hypothesis can be explained as follows:

\section{f. Sixth Hypothesis Test (H6)}

The sixth hypothesis test examines the role of trust in mediating the effect of the pricing rate (price level) on the decision to purchase a car on credit. Based on table 9, the results of hypothesis testing obtained are: T-statistic $2.614>1.96$ and P-value $0.009<0.05$. So the sixth hypothesis is accepted, trust mediates the effect of the pricing rate on purchasing decisions, meaning that if the pricing rate (price level) provided is appropriate and competitive, it will increase consumer confidence, which will further increase the decision to purchase a car on credit.

\section{g. Seventh Hypothesis Test (H7)}

The seventh hypothesis test tested the role of trust in mediating the influence of word of mouth (wom) on the decision to buy a car on credit. Based on table 9, the results of hypothesis testing obtained are: T-statistic $2.204>1.96$ and P-value $0.028<0.05$. So the seventh hypothesis is accepted. Trust mediates the influence of word of mouth on purchasing decisions, meaning that if positive word of mouth (wom) will increase consumer confidence, this will impact car-buying decisions on credit.

\section{CONCLUSION}

Based on the research that has been done, the conclusions are as follows:

1. Pricing rate (price level) affects purchasing decisions. This means that the high or low pricing rate (price level) that is set will affect buying a car on credit.

2. Word of mouth (wom) affects purchasing decisions. This means that positive word of mouth (wom) will affect buying a car on credit.

3. Pricing rate (price level) affects trust. This means that an appropriate and competitive pricing rate will affect the level of consumer confidence.

4. Word of mouth (wom) affects trust. This means that positive word of mouth (wom) will affect consumer confidence.

5. Trust affects purchasing decisions. This means that if consumer confidence increases, it will affect buying a car on credit.

6. Trust mediates the effect of the pricing rate on purchasing decisions. This means that if the pricing rate (price level) provided is appropriate and competitive, it will increase consumer confidence. This will further increase the decision to purchase a car on credit.

7. Trust mediates the effect of word of mouth (wom) on purchasing decisions. This means that if positive word of mouth (wom) increases consumer confidence, this will impact the decision to buy a car on credit.

From this research, we proposed some suggestions such as:

1. For further research interested in researching the factors that influence purchasing decisions, it is better to connect with other variables that have not been studied that may affect this study.

2. The population of this study is all consumers who have purchased a car on credit at the Maybank Finance area of West Java which consists of 4 city branches, namely: Bandung, Bogor, Cirebon, and Karawang, both of those that have been paid off and those that are still running, where the number of the population for consumers who are still running is known, but for the people of consumers who have paid off it is not known, so the overall population in this study is unknown. It is hoped that further researchers can expand the coverage area in population collection. It is also recommended to increase the number of samples in the study to represent the actual situation more.

3. This research was conducted by filling out questionnaires through Google Forms face-to-face directly to respondents who were visiting the Maybank Finance office in the West Java area, namely Bandung, Bogor, Cirebon, and Karawang city branches, it is recommended for further researchers to be able to conduct face-to- 
face research directly, both to respondents who are visiting the Maybank Finance office, or those who are not so that the results obtained are more accurate.

4. For Maybank Finance, to maintain the pricing rate given because it dramatically influences the decision to purchase a car on credit. If the pricing rate is appropriate and lower than other competitors, it will increase buying a vehicle on credit.

5. For Maybank Finance, it is hoped that it will continue to increase and maintain consumer confidence in its company because the trust from consumers in Maybank Finance will positively impact the decision to buy a car on credit.

6. For Maybank Finance, it must provide the best service to give a good impression to consumers. It offers attractive pricing rates and maintains consumer confidence so that with a good experience, consumers will communicate a positive word of mouth (wom) about Maybank Finance. It will attract other potential consumers to make car purchases on credit through Maybank Finance.

\section{REFERENCES}

[1] Alma, Buchari. (2016) Manajemen Pemasaran dan Pemasaran Jasa. Bandung: Alfabeta.

[2] Amitay, Y., Winoto Tj, H., Saparso \& Wahyoedi, S. (2020). The Impact of Celebgram Endorsement on Purchase Intention: The Mediating Effect of Customer Attitude and Brand Awareness. 8th International Conference on Entrepreneurship and Business Management (ICEBM) UNTAR.

[3] Andriansyah. (2015) Manajemen Transportasi dalam Kajian dan Teori. Jakarta Pusat : Fakultas Ilmu Sosial dan Ilmu Politik Universitas Prof. Dr. Moestopo Beragama.

[4] Arif, Muhammad dan Adisya Nadira Putri. (2021) The Influence of Company Image and Trust and Word of mouth on Purchasing Decisions of Postal Express Services. International Journal of Economic, Technology and Social Sciences. Vol. 1, No. 1. (hlm. 49-60)

[5] Daryanto. (2013) Inovasi Pembelajaran Efektif. Bandung : Yrma Widya.

[6] Engel, Blackwell, Miniard. (2012) Perilaku Konsumen. Tangerang : Binarupa Aksara.

[7] Fansisca, Jessi dan Saparso. (2014) Analisis Pengaruh Brand Image, Brand Trust dan Psychology terhadap Purchase Decision Laptop di Lingkungan Mahasiswa. (Studi Kasus : Universitas Kristen Krida Wacana, Universitas Tarumanegara dan Universitas Trisakti Jakarta Barat) Jurnal Ilmiah Manajemen Bisnis. Vol. 14, No. 2. (hlm. 7986)

[8] Fhonna, Ria Amalia dan Sorayanti Utami. (2018) Pengaruh Electronic Word of Mouth Terhadap Keterlibatan Keputusan Pembelian Dan Kepercayaan Sebagai Pemediasi Pada Konsumen Shopee Di Universitas Syiah Kuala. Jurnal IImiah Mahasiswa Ekonomi Manajemen. Vol. 3, No. 3. (hlm. 20-32)

[9] Ghozali, I dan Latan, H., (2015) Konsep, Teknik, Aplikasi Menggunakan SmartPLS 3.0 untuk Penelitian Empiris. Semarang : Badan Penerbit Undip.

[10] Gitosudarmo. (2014) Manajemen Pemasaran. Yogyakarta : Badan Penerbit Fakultas Ekonomi, Universitas Gadjah Mada.

[11] Hasan, Ali. (2013) Marketing dan Kasus-Kasus Pilihan. Yogyakarta : Media Presindo.

[12] Haekal, Muhammad Erlandy, Suharyono dan Edy Yuliyanto. (2016) Pengaruh Electoronic Word of Mouth Terhadap Kepercayaan Dan Keputusan Pembelian. (Survei Pada Konsumen Produk Fashion Followers Akun Instagram Erigostore). Jurnal Administrasi Bisnis (JAB). Vol. 40, No. 2. (hlm. 162-18)

[13] Japarianto, Edwin dan Stephanie Adelia. (2020) Pengaruh Tampilan Web Dan Harga Terhadap Minat Beli Dengan Kepercayaan Sebagai Intervening Variable Pada E-Commerce Shopee. Jurnal Manajemen Pemasaran. Vol. 14, No. 1. (hlm. 35-43)

[14] Kotler, Philip T. dan Gary Armstrong. (2020). Principles of Marketing. Edisi 18 Global Edition. Pearson.

[15] Masturi, Hajir dan Resti Hardini. (2017) Pengaruh Kualitas Produk, Tingkat Harga Dan Word of Mouth Terhadap Keputusan Pembelian Karate-Gi Merek Hokido Di Lima Dojo Wilayah DKI Jakarta. Jurnal Ilmu Manajemen Oikonomia. Vol. 13, No. 2. (hlm. 87-98)

[16] Maurencia, Evelyn, Hery Winoto Tj dan Soegeng Wahyoedi. (2021) The Influence of Celebrity Endorsement, Product Quality and Price on Purchase Interest of Kanzler Single Sausage Products. SIASAT Journal of Social, Cultural and Political Studies, Vol. 6, No, 1. (hlm. 59-72) 
[17] Murwatiningsih dan Erin Puri Apriliani. (2018) Pengaruh Risiko Dan Harga Terhadap Keputusan Pembelian Melalui Kepercayaan Konsumen. Jurnal Dinamika Manajemen, Vol. 4, No. 2. (hlm. 184-191)

[18] Octavini, Nanda Andreas. (2020) Pengaruh Electronic Word of Mouth Dan Pengetahuan Produk Terhadap Kepercayaan Dan Dampaknya Pada Keputusan Pembelian Online Di Sociolla Pada Mahasiswi S1 Fakultas Ekonomi Dan Bisnis Universitas Muhammadiyah Metro Lampung. Journal of Economic Management. Vol. 1, No. 1. (hlm. 34-50)

[19] Peter dan Olson. (2013). Perilaku Konsumen dan Strategi Pemasaran. Edisi Kesembilan. Diterjemahkan oleh : Diah Tantri Dwiandani. Jakarta : Salemba Empat.

[20] Pratiwi, Yuly Rahmi. (2017) Pengaruh Word of Mouth Communication Terhadap Keputusan Pembelian Konsumen Pada Boardgame Lounge Smart Cafe Pekanbaru. Jurnal Online Mahasiswa FISIP. Vol. 4, No. 1. (hlm. 1-15)

[21] Priansa, Donni Juni. (2017) Komunikasi Pemasaran Terpadu. Bandung : Pustaka Setia.

[22] Putra, Dimas Erlangga dan Dinalestari Purbawati. (2019) Pengaruh Tingkat Harga, Kualitas Produk Dan Word of Mouth Terhadap Keputusan Pembelian. (Studi Pada Konsumen Loffle Pop Up Dessert). Jurnal Ilmu Administrasi Bisnis. Vol. 8, No. 4. (hlm. 1-9)

[23] Rico, Melitina Tecoalu, Soegeng Wahyoedi dan Eka Desy Purnama. (2018) The Effects of Trust, Service Quality and Perceived Value on Satisfaction and Their Impact on Loyalty. Proceedings of the 7th International Conference on Entrepreneurship and Business Management - ICEBM Untar. (hlm 325-330)

[24] Sernovitz, Andy. (2014).Word of Mouth Marketing: How Smart Companies get People Talking. New York : Kaplan Inc.

[25] Solimun, Adji Achmad Rinaldo Fernandes dan Nurjannah. (2017) Metode Statistika Multivariat, Pemodelan Persamaan Struktural. (SEM) Pendekatan WarpPLS. Malang : Universitas Brawijaya Press.

[26] Sugiyono. (2018). Metode Penelitian Kombinasi (Mix Methods). Bandung : Alfabeta.

[27] Sukawati. (2018) Pengaruh Kepercayaan, Harga Dan Kualitas Produk Terhadap Keputusan Pembelian Melalui Internet Di Kota Makassar. Phinisi Integration Review. Vol. 1, No. 2. (hlm. 190-200)

[28] Suryani, Tatik. (2013) Perilaku Konsumen di Era Internet. Yogyakarta : Graha Ilmu.

[29] Swastha, Basu dan Irawan. (2014). Manajemen Pemasaran Modern. Yogyakarta : Liberty.

[30] Tjiptono, Fandy dan Greforius, Chandra. (2016). Pemasaran Jasa (Prinsip, Penerapan, dan Penelitian). Yogyakarta : Andi Offset.

[31] Umar, H. (2019). Metode Penelitian Untuk Skripsi dan Tesis Bisnis. Jakarta : Rajawali Pers.

[32] Wahyoedi, S., \& Winoto, H. (2018). Pengaruh Religitas, Kualitas Layanan Dan Trust Terhadap Loyalitas Nasabah Bank Syariah Di Kota Bogor. Jurnal Riset Ekonomi Dan $\quad$ Manajemen, $\quad 189$. https://doi.org/10.17970/jrem.17.170204.id

[33] Winoto, Hery Tj. (2020) Pengaruh Kualitas Produk dan Harga Terhadap Keputusan Pembelian Minuman Bobba yang Dimediasi dengan Strategi Promosi. Syntax Literature: Jurnal Ilmiah Indonesia. Vol. 5, No. 12. (hlm. 15661575) 